Acta Theriologica 44 (2): 173-182, 1999.

PL ISSN 0001-7051

\title{
Badger Meles meles sett site selection in low density Mediterranean areas of central Spain
}

\author{
Emilio VIRGÓS and Jorge G. CASANOVAS
}

\begin{abstract}
Virgós E. and Casanovas J. G. 1999. Badger Meles meles sett site selection in low density Mediterranean areas of central Spain. Acta Theriologica 44: 173-182.

We studied the habitat selection of badgers Meles meles (Linnaeus, 1758) in a mountainous area of central Spain through badger sett location, in relation to a series of variables related to the micro and macrohabitat structure considered potentially important for habitat requirements (food and shelter) were choosen.

The analysis was carried out using the Savage index (W) for use/availability data. Badgers in this area prefer mid-elevation mountain areas, where both dehesas (open woods with pastures) and pine forests prevail. Lower elevation areas were avoided. Badgers are associated with watercourses, but we found, no significant differences for distance to villages or for roughness. Badgers preferred trees and rock covered areas, which provided shelter places.

Badger conservation in Mediterranean mountains requires mosaic habitats (dehesas). The low density that has been found could be due both to human factors (eg persecution and habitat loss) and to a probable low suitability value of Mediterranean environments for the badger.

Department of Animal Biology I (Vertebrate Zoology), Faculty of Biological Sciences. Universidad Complutense, E-28040 Madrid, Spain, e-mail: evirgos@eucmax.sim.ucm.es (EV); C/Bernardina García, 27, E-28047 Madrid, Spain (JGC)

Key words: Meles meles, conservation, low density, mediterranean, mosaic habitats, mountains, sett location
\end{abstract}

\section{Introduction}

The European badger Meles meles (Linnaeus, 1758) is a widely distributed mustelid with versatile ecological requirements (Neal 1986). It has been well studied throughout Occidental Europe, especially in the United Kingdom and The Netherlands (Kruuk 1989). Information is available about its distribution and status (Wiertz and Vink 1986, Cresswell et al. 1989, Griffiths and Thomas 1993, Reason et al. 1993, Smal 1993); aspects related to behavioural plasticity in different environmental conditions (Kruuk 1989); diet (Kruuk 1989, Roper 1994); and sett distribution in relation to habitat characteristics (Zejda and Nesvadbova 1983, Thornton 1988, Skinner et al. 1991a, b).

Several studies have demonstrated the sensitivity of this species to human disturbance (Wiertz and Vink 1986, Skinner et al. 1991a, b, Zee et al. 1992, Reason et al. 1993). All were conducted in central Europe where conditions are especially 
favourable for this species (Griffiths and Thomas 1993). The Mediterranean region is at the southwest limit of the badger's distribution area (Griffiths and Thomas 1993) and, therefore, populations may be more affected by small changes in ecological conditions (Brown 1984). Mediterranean environments are predominantly very dry and the badger is more scarce in xeric environments than rainy areas (Griffiths and Thomas 1993). However, our knowledge of its ecology and conservation from the Mediterranean area is very limited (Pigozzi 1988, Virgós et al. 1993, Martín et al. 1995, Rodríguez et al. 1996). An understanding of the areas selected by badgers for setts is useful in determining the species ecological requirements (Thornton 1988, Skinner et al. 1991a, b, O'Corry-Cröwe et al. 1993) and is, therefore, potentially useful in management decisions.

In this study, we analyzed factors affecting badger sett distribution in a mountainous area of central Spain and have provided some recommendations for conservation.

\section{Material and methods}

\section{Study area}

The study area was located in the Alto Manzanares Regional Park and its surroundings $\left(41^{\circ} 40^{\prime} \mathrm{N}\right.$, $4^{\circ} 10^{\prime} \mathrm{E}$ ), on the southern slope of the Guadarrama mountains (central Spain), covering a total area of 65.000 ha.

This natural area is characterized by its severe altitudinal gradient and by its localized dense human population. As a consequence of the pronounced orography, all vegetation types characteristic of central Spain can be found. The low-elevation level was covered by holm-oak forest (Quercus ilex) and its serial succession formations (eg Cistus, Retama). The holm oak forests is between 600 to 900 metres above sea level (a.s.l.) and is the most typical Mediterranean habitat and the most inhabited by people. Between $900-1200 \mathrm{~m}$ a.s.l. are the dehesas, they are used as feeding pastures for cattle and are dominated by Pyrenaean oak (Quercus pyrenaica) and ash trees (Fraxinus angustifolia). They are characterized by open formations with little scrub and higher moisture than in the Mediterranean holm-oak forests. At higher elevation there is a strip in which oak forest has been replaced by pine forest (eg Pinus sylvestris). These are between 1200-1700 m a.s.l. and have different degrees of scrub coverage depending on the predominant type of land use. This is colder and wetter level and the snow is common. The highest elevation $(1700-2100 \mathrm{~m}$ a.s.l.) are not forested and have a typical high mountain climate. These were not included because badger do not occur here.

Further information about climate and vegetation types of the study area can be found in Rivas-Martínez (1982).

\section{Survey procedures}

Field work was carried out between 1989 and 1991, from October to April. The survey consisted of a search for badger setts, using a procedure similar to other studies (Thornton 1988, Cresswell et al. 1989, O ' Corry-Cröwe et al. 1993). Sampling was carried out by four people with experience in locating and identifying of setts. Badger setts were not classified according to conventional criteria (see Thornton 1988) because of problems in applying these in our study area, where the use of the badger setts is erratic (eg is not possible define main setts or outliers, see also Skinner et al. 1991a).

Variables 1-5 and 8 (see Table 1) were quantified on 1:50.000 topographical maps onto which the locations of setts were plotted. The remaining variables: habitat type, landscape use and tree, shrub, rock and pasture cover were measured in the field by visual estimation within circular-plots of $25 \mathrm{~m}$ radius around each sett. The selection of this sampling unit is a convention based in procedures used 
Table 1. Description of the topographic (1-5), habitat, land use and soil types (6-8) and vegetation structure variables (9-12) used in this study.

\begin{tabular}{|c|c|}
\hline Variable & Measure \\
\hline 1. Elevation & Height above sea level in each point \\
\hline 2. Roughness & $\begin{array}{l}\text { Number of } 50 \mathrm{~m} \text { height level curves included in } 500 \mathrm{~m} \text { radius around each } \\
\text { point in the topographical map }\end{array}$ \\
\hline 3. Distance to water & Minimum distance (in metres) from each point to the nearest watercourse \\
\hline 4. Distance to village & Minimum distance (in metres) from each point to the nearest village \\
\hline 5. Distance to road & $\begin{array}{l}\text { Minimum distance (in metres) from each point to the nearest road (any road } \\
\text { type) }\end{array}$ \\
\hline 6. Habitat & $\begin{array}{l}\text { Habitat type: holm oak forest, dehesa - a typical landscape with woods and } \\
\text { pastures - and pine forest in each point }\end{array}$ \\
\hline 7. Land use & Type of land use: cattle, forestry, recreative and game in each point \\
\hline 8. Soil type & $\begin{array}{l}\text { Type of soil (soil taxonomy classification) in each point: leptosols, cambisols, } \\
\text { others - regosols, fluvisols, etc }\end{array}$ \\
\hline 9. Tree cover & Tree canopy cover in 25 metres radius around each point \\
\hline 10. Shrub cover & Shrub cover in 25 metres radius around each point \\
\hline 11. Rock cover & Rock cover in 25 metres radius around each point \\
\hline 12. Pasture cover & Herb cover in 25 metres radius around each point \\
\hline
\end{tabular}

elsewhere (eg in vegetation and wildlife-habitat studies, see review in Morrison et al. 1992). The choosed $25 \mathrm{~m}$ radius may be useful because is a measure of small-scale habitat features, and we assume that the badger select their sites for badger setts according with small-scales characteristics. However, it is possible that the species select their setts sites at other scales (see Doncaster and Woodroffe 1993) and, therefore, that the obtained results were wrongs. The problem of the scale in habitat selection studies has been largely discussed (eg Morris 1987, Wiens 1989, Kotliar and Wiens 1990). Thus, the different life processes can be viewed in a hierarchical manner (Wiens 1989). The decisions at any level may be simultaneously affected by factors associated to levels below and above in the hierarchy (Kotliar and Wiens 1990). In general, it is recommended choose the scale according to relevant questions of the study, however, because studies about the perceptual cues used by animals in their decision-making activities are scarce in the literature (but see Ims 1995, and references therein), may be reasonable use conventional methods and scales, as the cicular plot method to estimate vegetation structure variables.

All variables were considered related to food or/and shelter for badgers, in accordance with previous studies (Thornton 1988, Skinner et al. 1991a, b, O'Corry-Cröwe et al. 1993). Availability of the first set of variables and soil type were quantified using 100 random points over the topographical and soil maps $(1: 50.000)$. For the second group, the availability was determined by carrying out 546 transects of $500 \mathrm{~m}$ scattered around the study area, in which values of each variable were estimated within circular-plots of $25 \mathrm{~m}$ radius spaced at $125 \mathrm{~m}$ intervals.

\section{Data analyses}

We used a chi-square goodness-of-fit test to determine whether or not badgers used the variables considered in proportion to availability. The Savage selectivity index (Manly et al. 1993) was used to measure between intervals or classes for each variable. The Savage selectivity index (Wi) is obtained 
from the expression: $U_{i} / P_{i}$ where $U_{i}$ is defined as the proportion of used units and $P_{i}$ as the proportion of available units. Selection was considered positive when Wi was significantly higher than one and negative when the value is significantly lower than one. The statistical significance of the indices was tested by comparing the statistic $(\mathrm{Wi}-1)^{2} /$ standard error $(\mathrm{Wi})^{2}$ with the corresponding critical value of a chi-square distribution with one degree of freedom (Manly et al. 1993). We estimated standard error of $\mathrm{Wi}$ on the null hypothesis that there was no selection, so that the standard error (SE) of Wi was approximated by the square root of $\left(1-\mathrm{P}_{\mathrm{i}}\right) /\left(\mathrm{u}+\mathrm{X} \mathrm{P}_{\mathrm{i}}\right)$, where $\mathrm{u}+$ is the number of samples with sett presence for this interval or class, and $P_{i}$ is the proportion of available units within this interval or class. Statistical significance of these chi-square values was fixed at $p<0.05$, but in order to avoid type I errors, Bonferroni sequential corrections were applied (Rice 1989).

\section{Results}

We found a total of 26 badger setts $\left(0.04 \mathrm{setts} / \mathrm{km}^{2}\right)$. The distribution of the badger setts in the different habitats was as follows: 4 (holm-oak), 10 (dehesas), 12 (pine forest).

These badger setts rarely have been used along all year, rather its use is erratic and any seasonal trend were found during the study period (more infornation on badger sett location and other charcteristics can be seen in Table 2).

Table 2. Sett characteristics (location and number of entrances) according to habitat types considered.

\begin{tabular}{lcc}
\hline Habitat & $\begin{array}{c}\text { Number of entrances } \\
\text { (mean and range) }\end{array}$ & Sett location \\
\hline Holm oak & $2(2)$ & $100 \%$ below rocks \\
Dehesa & $8.2(2-30)$ & $94 \%$ below rocks \\
Pine & $2.5(2-4)$ & $6 \%$ underground \\
\hline
\end{tabular}

\section{Topographical variables}

The minimum distance to watercourses was the only variable with significant results in the goodness of fit test (see Table 3). The Savage index showed avoidance at elevations between $600-800 \mathrm{~m}$ a.s.l. There was a positive selection for places located less than $200 \mathrm{~m}$ from water, but no significant differences at other distances (see Table 3). The chi-square goodness of fit test showed no significant differences for slope, distance to villages and roads (Table 3).

\section{Habitat type, land use and soil type}

These variables presented significant values for the goodness of fit test (Table 3). For soil type, only the category "others" (eg regosols, fluvisols) were significant 
Table 3. Chi-square values for each variable and category; number of badger setts $(n)$; expected values (after its environmental availability) and Savage index in each category (W). ns - no significant differences, ${ }^{*}-p<0.05,{ }^{* *}-p<0.01,{ }^{* * *} p-<0.001$, " + " - significant positive selection, “-" - significant avoidance.

\begin{tabular}{|c|c|c|c|c|}
\hline Variable & $n$ & Expected value & Savage index (W) & $\chi^{2}$ \\
\hline 1 & 2 & 3 & 4 & 5 \\
\hline Elevation & & & & $7.6(\mathrm{~ns})$ \\
\hline $600-800$ & 0 & 5.1 & 0 & $6.41(-)$ \\
\hline $800-1000$ & 9 & 7.7 & 1.16 & 0.28 \\
\hline $1000-1200$ & 7 & 4.9 & 1.43 & 1.11 \\
\hline $1200-1400$ & 7 & 3.3 & 2.10 & 4.57 \\
\hline$>1400$ & 3 & 4.9 & 0.61 & 0.91 \\
\hline Roughness & & & & $4.00(\mathrm{~ns})$ \\
\hline $1-2$ & 7 & 10.4 & 0.40 & 1.79 \\
\hline $3-4$ & 5 & 5.7 & 0.21 & 0.07 \\
\hline $5-10$ & 12 & 6.9 & 0.27 & 5.06 \\
\hline$>10$ & 2 & 3.0 & 0.11 & 0.33 \\
\hline Distance to water & & & & $6.7(*)$ \\
\hline $0-200$ & 17 & 10.4 & 1.61 & $6.67(+)$ \\
\hline $200-600$ & 8 & 11.5 & 0.69 & 2.04 \\
\hline$>600$ & 1 & 4.1 & 0.24 & 2.81 \\
\hline Distance to village & & & & $2.71(\mathrm{~ns})$ \\
\hline $0-1000$ & 4 & 6.3 & 0.64 & 1.05 \\
\hline $1000-2000$ & 7 & 6.4 & 1.09 & 0.06 \\
\hline $2000-3000$ & 10 & 6.4 & 1.55 & 2.63 \\
\hline$>3000$ & 5 & 6.9 & 0.72 & 0.73 \\
\hline Distance to road & & & & $3.84(\mathrm{~ns})$ \\
\hline $0-500$ & 6 & 4.5 & 1.29 & 0.48 \\
\hline $500-1500$ & 11 & 7.5 & 1.47 & 2.34 \\
\hline $1500-2500$ & 4 & 5.9 & 0.67 & 0.81 \\
\hline$>2500$ & 5 & 8.1 & 0.61 & 3.01 \\
\hline Habitat & & & & $30.59^{(* * *)}$ \\
\hline Holm oak & 4 & 18.1 & 0.22 & $38.00(-)$ \\
\hline Dehesa & 10 & 2.6 & 3.76 & $22.66(+)$ \\
\hline Pine & 12 & 5.3 & 2.26 & $72.04(+)$ \\
\hline Land use & & & & $14.47^{(* *)}$ \\
\hline Cattle & 10 & 4.8 & 2.10 & 7.04 \\
\hline Forestry & 3 & 2.6 & 1.15 & 0.06 \\
\hline Recreative & 11 & 6.9 & 1.59 & 3.31 \\
\hline Game & 2 & 11.7 & 0.17 & $14.95(-)$ \\
\hline
\end{tabular}


Table 3 - concluded.

\begin{tabular}{lrrlc}
\hline \multicolumn{1}{c}{1} & 2 & 3 & 4 & 5 \\
\hline $\begin{array}{l}\text { Soil type } \\
\text { Leptosols }\end{array}$ & 13 & & & $7.76\left(^{*}\right)$ \\
Cambisols & 13 & 12.4 & 1.05 & 0.04 \\
others & 0 & 8.6 & 1.52 & 3.44 \\
Tree cover & & 5.0 & 0 & $6.28(-)$ \\
$0-25$ & 8 & & & $12.74\left(^{* *}\right)$ \\
$25-50$ & 5 & 15.9 & 0.50 & $10.13(-)$ \\
$>50$ & 13 & 6.2 & 0.80 & 0.31 \\
Shrub cover & & 3.9 & 3.36 & $25.36(+)$ \\
$0-25$ & 13 & & & $1.88(\mathrm{~ns})$ \\
$25-50$ & 2 & 13.6 & 0.96 & 0.05 \\
$>50$ & 11 & 4.9 & 0.39 & 2.13 \\
Rock cover & & 7.5 & 1.5 & 2.32 \\
$0-25$ & & & & $36.96(* * *)$ \\
$25-75$ & 3 & 18.5 & 0.16 & $44.74(-)$ \\
$>75$ & 21 & 5.8 & 3.61 & $50.98(+)$ \\
Pasture cover & 2 & 1.7 & 1.17 & 0.05 \\
$0-25$ & & & & $0.45(\mathrm{~ns})$ \\
$>25$ & 5 & 19.3 & 0.75 & 0.59 \\
& & 6.7 & & 0.53 \\
\hline
\end{tabular}

avoided. It is remarkable that no badger sett was located outside cambisols or leptosols, which are the most abundant soils in the study area.

All Savage indexes were significant for the habitat type. Holm-oak forest was avoided by badgers, but pine-forests and dehesas showed clear positive selection (Table 3).

With regard to land use, which is closely related to habitat type in this area, the Savage index showed badgers selected cattle grazing land and avoided areas occupied by game activities.

\section{Vegetation structure}

Badgers selected tree-cover and rock-cover (Table 3). For tree cover there was clear selection for wooded places ( $>50 \%$ cover) and avoidance of more deforested areas $(0-25 \%)$. For rock-cover, chi-square analysis indicated that badger selected places with $25-75 \%$ cover and avoided less rocky ground $(0-25 \%)$. Pasture and shrub cover did not show significant selection from availability (Table 3 ). 


\section{Discussion}

Badger sett density in our study area is very low compared with other surveys reported in the literature (see Smal 1993 and references therein). Following Neal (1986) this density would be categorised as "scarce" (3-7 setts $\left./ 100 \mathrm{~km}^{2}\right)$.

In other European countries the badger is mainly an inhabitant of mosaic habitats, especially of deciduous woodland with pasture (Neal 1986, Wiertz and Vink 1986, Thornton 1988, Kruuk 1989). Its ability to adapt to very different habitats is well known (Roper 1994), and it can even live in arid, mountainous or farm habitats (Neal 1986, Kruuk 1989, Rodríguez and Delibes 1992). In the Sierra de Guadarrama it maintains a preference for habitats combining woodland and pasture (dehesas), and are much less abundant in holm-oak forests, where low environmental heterogeneity and xeric conditions prevail (Rivas-Martínez 1982). Higher elevation habitats (pine forest with scrub highland) were not as readily selected as the dehesas. Pine forests are poor habitat for badgers (but see Cresswell et al. 1989, O'Corry-Cröwe et al. 1993) because of their poor cover and low supply of trophic resources (Neal 1986). However, pine forests at lower altitudes appear to provide good conditions for badgers, because these have both well wooded and rocky shelter areas. In these areas, badger setts usually were located on the boundary between pine forest and either pastures or oak forest, allowing easy access to rich trophic habitat (see also Zejda and Nesvadbova 1983, O'Corry-Cröwe et al. 1993).

The habitat variables that seem most indicative of badger presence include: existence of woodland, rocky places, proximity to watercourses, and good soil. These variables agree with those cited by Neal and Roper (1991) for British badgers (good soils and tree cover). The need for good soils has been demonstrated in previous studies (Dunwell and Killingley 1969, Thornton 1988, Roper 1993). Badgers in the mountains of central Spain did not positively select the most important soil-types (cambisols and leptosols) but they did reject other types, which are less suitable for digging (Monturiol 1987). Clearly, soil diggability is a characteristic important when badgers looking for a place for a sett (Thornton 1988). However, the weak significance of this variable suggests that soil type is not particularly important in our study area. Alternatively, we may consider that the good soils are very abundant, and hence, do not show as selected.

The presence of rocks has not been previously suggested to be a key factor, perhaps because rocks are absent in many of the previously studied areas. Rocks could act as refuges in case of disturbance, besides permitting good thermic isolation. The choice of wooded places is also probably related to protection (see also Neal and Roper 1991). This function is also provided by dense scrub (Neal 1986) or hedgerows (O'Corry-Cröwe et al. 1993) elsewhere. Scrub and pasture areas do not seem to be favourable for sett construction. Scrub areas usually have poor soils (Monturiol 1987), while the pastures provide little protection and are periodically flooded. The selection of places near to watercourses can be related to their association with other important resources such as fruit-producing bushes and good 
soils (Neal 1986). It is interesting that the badger does not seem to be especially affected by the massive human presence in our study area. We did not find that badgers avoided roads or areas around villages or habitats with human presence. These findings contradict evidence from other countries (Wiertz and Vink 1986, Åaris-Sörensen 1987, Skinner et al. 1991a, b, Zee et al. 1992), but the low density found could be a consequence of the overall high human density in this area. In addition, human settlements were concentrated in the "a priori" optimal habitats for badgers ( $800-1200 \mathrm{~m}$ altitude). Conversely, game areas were avoided and it is possible that badgers were influenced by human persecution (see Cresswell et al. 1989, Reason et al. 1993), especially in low mountain areas. In summary, badger rarity in our study area appears to be attributed to the overall low quality of the environment $(70 \%$ of these mountains were xeric holm oak forests and associated shrub) and the increase of human settlements in the Sierra de Guadarrama will probably affect badger populations through habitar loss and direct persecution.

This selection pattern seems to coincide with results from more northerly areas (Roper 1993), suggesting that the environmental factors influencing badger sett location are the same in different regions. This is consistent with the hypothesis that the badger sett is a limiting resource with the maximal survival value (Neal and Roper 1991, Doncaster and Woodroffe 1993, Roper 1993) and, therefore, of critical conservation importance.

Badger conservation in Mediterranean areas requires the existence of man's traditional activities in the mountains (extensive livestock farming, see also Kruuk 1989) and the limitation of human development and game in low-lying mountain areas. Policies that encourage traditional agricultural practices would apparently benefit this species. Moreover, withdrawal of areas from use that have been used for agricultural purposes over the last 30 years would favour certain species that requires areas of dense scrub (Tellería and Sáez-Royuela 1984), but this would be detrimental for species such as the badger which are rarely found in this vegetation. Future studies should investigate the important impact that human activities can have on the ecology and abundance of the badger in Mediterranean areas.

Acknowledgements: We wish to thank the following people for their help and contributions to this work: T. Blázquez, Y. Cortés, D. García, F. J. Samblás, R. Martínez and M. A. García for field advices; G. G. Nicola, G. P. Farinós and T. J. Roper for their help with translation; J. L. Tellería, T. J. Roper, J. W. H. Conroy and two anonymous referees for suggestions to early versions of the manuscript. This work was a contribution to PB92/0238 DGICYT (Spanish Ministry of Education and Science).

\section{References}

Åaris-Sörensen J. 1987. Past and present distribution of badgers, Meles meles, in the Copenhaguen area. Biological Conservation 41: 159-165.

Brown J. H. 1984. On the relationship between distribution and abundance of species. The American Naturalist 124: 255-279.

Cresswell P., Harris S., Bunce R. G. H. and Jefferies D. J. 1989. The badger (Meles meles) in Britain: present status and future population changes. Biological Journal of Linnean Society 38: 91-101. 
Doncaster C. P. and Woodroffe R. 1993. Den site can determine shape and size of badger (Meles meles) territories: implications for group-living. Oikos 66: 88-93.

Dunwell M. R. and Killingley A. 1969. The distribution of badger setts in relation to the geology of the chilterns. Journal of Zoology, London 158: 204-208.

Griffiths D. H. and Thomas H. J. 1993. The status of the Badger in Europe. Mammal Review 23: $17-58$.

Ims R. A. 1995. Movement patterns related to spatial structure. [In: Mosaic landscapes and ecological processes. L. Hansson, L. Fahrig and G. Merriam, eds]. Chapman and Hall, London: 85-109.

Kotliar N. B. and Wiens J. A. 1990. Multiple scales of patchiness and patch structure: a hierarchical framework for the study of heterogeneity. Oikos 59: 253-260.

Kruuk H. 1989. The social Badger. Oxford University Press, Oxford: 1-180.

Manly B., Mc Donald L. and Thomas D. 1993. Resource selection by animals. Chapman and Hall, London: 1-192.

Martín R., Rodríguez A. and Delibes M. 1995. Local feeding specialization by badgers (Meles meles) in a Mediterranean environment. Oecologia 101: 45-50.

Monturiol F. 1987. Los suelos. [In: La naturaleza de Madrid. E. Fernández-Galiano and A. Ramos, eds]. CAM. Consejería de Agricultura y Ganadería, Madrid: 135-151

Morris D. W. 1987. Ecological scale and habitat use. Ecology 68: 362-369.

Morrison M. L., Marcot B. G. and Mannan R. W. 1992. Wildlife habitat relationships. Concepts and applications. University of Wisconsin Press, Wisconsin: 1-343.

Neal E. G. 1986. The natural history of badgers. Croom Helm, London and Sidney: 1-238.

Neal E. G. and Roper T. J. 1991. The environmental impact of badgers (Meles meles) and their setts. [In: The environmental impact of burrowing animals and animal burrows. P. S. Meadows and A. Tufail, eds]. Zoological Society of London, London: 89-106

O'Corry-Cröwe G., Eves J. and Hayden T. J. 1993. Sett distribution, territory size and population density of badgers (Meles meles) in east Offaly. [In: The Badger. T. J. Hayden, ed]. Royal Irish Academy, Dublin: 35-56

Pigozzi G. 1988. The diet, food availability and use of space in the European badger in the Maremma Natural Park, Central Italy. Monitore Zoologia Italiana 22: 545-546.

Reason P., Harris S. and Cresswell P. 1993. Estimating the impact of past persecution and habitat changes on the numbers of badgers (Meles meles) in Britain. Mammal Review 23: 1-15.

Rice W. R. 1989. Analyzing tables of statistical tests. Evolution 43: 223-225.

Rivas-Martínez S. 1982. Mapa de las series de vegetación de la provincia de Madrid $(1: 200000)$. Diputación de Madrid. Servicio Forestal y Medio Ambiente, Madrid.

Rodríguez A. and Delibes M. 1992. Food habits of badgers (Meles meles) in an arid habitat. Journal of Zoology, London 227: 347-350.

Rodríguez A., Martín R. and Delibes M. 1996. Space use and activity in a Mediterranean population of badgers Meles meles. Acta Theriologica 41: 59-72.

Roper T. J. 1993. Badger setts as a limiting resource. [In: The Badger. T. J. Hayden, ed]. Royal Irish Academy, Dublin: 26-34

Roper T. J. 1994. The European Badger Meles meles: food specialist or generalist? Journal of Zoology, London 234: 437-452.

Skinner C. A., Skinner P. J. and Harris S. 1991a. An analysis of the factors affecting the current distribution of badger, Meles meles, setts in Essex. Mammal Review 21: 51-65.

Skinner C. A., Skinner P. J. and Harris S. 1991b. The past history and recent decline of badgers, Meles meles, in Essex: an analysis of some of the contributory factors. Mammal Review 21: 67-80.

Smal C. M. 1993. The National Badger Survey: preliminary results for the Irish Republic. [In: The Badger. T. J. Hayden, ed]. Royal Irish Academy, Dublin: 9-22

Tellería J. L. and Sáez-Royuela C. 1984. The large mammals of central Spain: an introductory view. Mammal Review 14: 51-56.

Thornton P. S. 1988. Density and distribution of badgers in South-West England: a predictive model. Mammal Review 18: 11-23. 
Virgós E., Casanovas J. G. and Samblás F. J. 1993. La importancia del factor escala en los estudios de selección del hábitat aplicados a conservación: el caso del Tejón (Meles meles) en la Sierra de Gudarrama. Aegypius 11: 71-75.

Wiens J. A. 1989. Spatial scaling in ecology. Functional Ecology 3: 385-397.

Wiertz J. and Vink J. 1986. The present status of the Badger, Meles meles, in the Netherlands. Lutra 29: 21-53.

Zee van der F. F., Wiertz J., Ter Braak C. J. F., Apeldoorn van R. C. and Vink J. 1992. Landscape change as a posible cause of the Badger, Meles meles, decline in the Netherlands. Biological Conservation 61: 17-22.

Zejda J. and Nesvadbova J. 1983. Habitat selection and population density of the badger (Meles meles) in Bohemia and Moravia. Folia Zoologica 32: 319-333.

Received 22 October 1997, accepted 12 February 1999. 